\title{
Social Studies Teacher Candidates' Perception of Digital Citizenship
}

\author{
Nurhak Cem Dedebali * \\ Sinop University, TURKEY
}

\author{
Iskender Dasdemir \\ Ege University, TURKEY
}

\section{Received: June 15, 2019 - Revised: July 28, 2019 - Accepted: August 15, 2019}

\begin{abstract}
With the rapid pace of technological and digital change, the use of mass communication and digital communication tools, and internet usage have become very prevalent and thus digital citizenship education has become a necessity for individuals so that they can effectively use these technologies. In this respect, in-class and out-of-class activities play a crucial role in developing students' digital citizenship competencies in social studies education. Teacher candidates' perception of digital citizenship will influence students as well. The objective of the current study is to identify the perception of the social studies teacher candidates towards digital citizenship. A descriptive cross-sectional screening model was utilized in the study. The sample of the study is composed of senior teacher candidates attending the Social Studies Teaching Department, Faculty of Education of Ege University in the 2016-2017 academic year. Digital Citizenship Attitude Scale was employed to identify the perceptions of teacher candidates towards digital citizenship. The analysis of the results in the context of subdimensions indicates that no statistically significant difference was found by the gender variable, however significant differences was observed in digital citizenship levels of the teacher candidates according to the variables of owning a personal computer, age and years of experience in computer use.
\end{abstract}

Keywords: Social studies, digital citizenship, technology.

To cite this article: Dedebali, N. C., \& Dasdemir, I. (2019). Social studies teacher candidates' perception of digital citizenship. International Journal of Educational Methodology, 5(3), 465-477. https://doi.org/10.12973/ijem.5.3.465

\section{Introduction}

In today's world, people are immensely influenced by the technology they use in their daily lives. In particular, technology has moved the interaction among people into a new dimension. This new dimension of communication has also brought a new concept of society characterized as "network society" and the individuals who live in this society have been defined as digital citizens (Castells, 2000).The concept of digital citizenship or accordingly the new society addresses to an evolution and change which our society today cannot resist (Kocadag, 2012).

In democratically governed nations, the citizen is defined as a person who is entitled to benefit all the legal rights and duties granted by a state to the people comprising its constituency. Individuals have these rights because of being born there or because of being given rights later and people who enjoy these rights are called citizen (Aslan, 2016). Citizenship is an identity accepted by all spheres of the society and this identity has welcomed technological advancements. Due to the rapid advances in our era, the perception of citizenship are constantly changing and evolving and the term of citizenship have been called as follows: ecological citizenship, environmental citizenship, constitutional citizenship, nationality law, European Union citizenship, global citizenship, multicultural citizenship and digital citizenship (Bakir, 2016; Kilinc, 2015).

We are now living in a fast paced technological era and thus information and communication tools are also influenced by these advancements. To illustrate, as a result of the cutting-edge communication technology, we can now access the internet everywhere in the world and distances do not matter anymore. Emerging in the wake of network society, digital citizenship is defined as a person who can effectively and efficiently use digital tools through advanced communication technology and respect moral rules and individual rights and freedoms in a virtual environment and use technological tools responsibly (Aslan, 2016).

In summary, the concept of digital citizenship addresses to individual's level of responsibility in line with the responsible and appropriate use of digital tools (Mossberger, Tolbert, \& McNeal, 2007).In today's era, digital tools have become indispensable part of people's lives. Digital tools shape our daily lives in terms of both socially and individually.

\footnotetext{
* Corresponding author:

Nurhak Cem Dedebali, Sinop University, Faculty of Education, Sinop - TURKEY. $\bowtie$ dedebali40@hotmail.com
} 
Because of the extensive usage of these tools, everyone is a digital citizen in a sense. Digital era removes the borders across the world and you may not have to be a citizen of a one nation in a digital world. For this reason, citizenship in digital world does not necessarily refer to obeying norms and code of ethics of just one nation. Global norms and rules are required to be a citizenship. Therefore, the current structure of the world has introduced the concept of global citizenship embracing the entire world. Each individual global citizen turns into a digital citizen when they act responsibly to communicate and seek information through using the internet.

In today's fast-paced world, evolving and changing technology refers to innovations attracting every spheres of society as well as innovations for the benefit of everyone in the society. Children with high levels of curiosity, in particular, are very keen on using digital tools in their developmental period. In this respect, the rate of using digital tools among new generation with young children has increased and this requires the necessity of raising awareness among young children of the importance of digital citizenship. The interest of young population to digital tools can also be explained with the notion of digital native. Considering the high interest of young generation to digital tools, this notion means a common sense of citizenship awareness has been ensured all around the world (Ribble, 2011). More clearly, the concept of digital native can also be used to define generations who were born into the digital world. The opposite of digital natives are digital immigrants. Digital immigrant is used to describe the generation of people who did not grow up in the digital age (Prensky, 2001).

The advancement of technology has surpassed the limits of human vision. Especially, the Internet removed the borders by bringing the world together. One of the duties of education systems in the world is to raise responsible citizens. At this point, social studies and other relevant lessons shoulder this responsibility. Therefore, the issue of digital citizenship must be further discussed in social studies lesson. In this respect, following nine themes of digital citizenship education are taken into consideration (Alberta, 2012):

- Digital Etiquette: It addresses the ability to act in a proper manner in the digital world as well as the rights and duties in online environment and responsible use of the technology.

- Digital Law: It refers to laws and rules in the digital world.

- Digital Rights and Responsibilities: It refers to having the right to defense yourself against cybercrime and freedom of personal expression.

- Digital Health: A description for psychical and physical well-being caused by digital life

- Digital Security: It means the protection of personal information in digital world

- Digital Literacy: It addresses to the awareness of individuals to appropriately use digital tools and to construct knowledge and communicate with others.

- Digital Communication: It is the exchange of information through the technology and the appropriate use of communication tools.

- Digital Commerce: It is buying and selling of goods online and the ability for an intelligent use of online possibilities like e-bank and e-commerce.

- Digital Access: Accessibility to digital medium everywhere.

When we look at the subdimension of the digital citizenship, these aforementioned subdimensions organize, facilitate individuals' social life, thereby allowing the individual to socialize and engage in society. Digital citizenship is considered as a tool to integrate a set of knowledge, skill, attitude and values gained in the school into life. In this respect, considering the definition of social studies, the fundamental objective of the social studies education is citizenship transmission.

According to Barr, Barth and Shermis (1978), social studies education is the cooperation of all disciplines as regards to individuals and community for the purpose of citizenship education. On the other hand, Sonmez (1994) defines social studies as the collection of the information which helps individuals to establish bonds with the society and thus to enable them to engage in society. According to Barth (1998), social studies is the interdisciplinary integration of social science and humanities concepts for the purpose of practicing problem solving and decision making for developing citizenship skills on critical social issues.

Considering the definitions of the social studies, we can thus contend that the objective of the social studies lesson is to furnish students with knowledge, skill, attitude and value required for being citizen. Another factor underlined in the definition of social studies is that the person cannot ignore the reality of the developing world. In a broad sense, the purpose of social studies lesson is to enable citizens to take part in the society. Individuals can adapt themselves to society only when they understand the reality of the time. From this perspective, social studies education also must keep up with the digital age, the most significant reality of the world, to keep pace with the conditions of developing and evolving world and to engage in society. One of the crucial steps of the adaptation mentioned is undoubtedly digital citizenship based on fundamental tools of our era, namely, the internet and computer. One of the current objectives of 
the social studies lesson is to raise individuals who can keep up with the times and to raise individuals who can fulfill the requirements of citizenship in digital platforms as well (MEB, 2018). In this context, the perceptions and views of social studies candidate teacher towards digital citizenship and whether they can engage in the society in terms of the digital citizenship are of vital importance. When the social studies teacher candidates begin to fulfill their teaching profession, their attitudes towards knowledge and skill that they will teach to students will also influence their professional life. Bearing in mind the definitions of social studies, the goal of raising citizen and fast-paced technological environment, the level of the social studies teacher candidates must be accordingly examined. It is thus believed that as social studies candidate teachers will equip students with digital citizenship skills when they begin to teaching, examining digital citizenship levels of the social studies teacher candidates is critically important and thereby fills a crucial gap in the literature.

The importance of the study is that the rapid developments in technology bring new topics (digital citizenship, e-state, e-commerce, social media etc.) as to the citizenship rights and responsibilities and a set of problems (digital divide, identity fraud, confidentiality of personal information, cyber fraud, cyber bullying etc.). In this respect, social studies teachers point out that in-class and out-of-class activities must take place to develop students' digital citizenship competencies in social studies (MEB, 2018). Because of the responsibility that teacher takes on in social studies curricula, there is a necessity to investigate affective behaviors of social studies teachers about digital citizenship. In this sense, it is believed that identifying the attitudes of social studies teacher toward digital citizenship will contribute to the field.

In this respect, the purpose of the current study was to examine digital citizenship levels of social studies teacher candidates. Accordingly, it is attempted to achieve the following sub goals:

1. Do digital citizenship levels of teacher candidates significantly differ by the variable of owning a personal computer?

2. Do digital citizenship levels of teacher candidates significantly differ by the gender variable?

3. Do digital citizenship levels of teacher candidates significantly differ by the age variable?

4. Do digital citizenship levels of teacher candidates significantly differ by the variable of years of experience in computer use?

\section{Methods}

This section provides methodological aspects of the study. In this sense, the research model, the study population and the sample size, the validity and reliability study of data gathering tools and other tests used for data analysis were presented.

\section{Research Model}

Quantitative methods and descriptive survey model was employed in the present study to identify an incident as it exists. The descriptive surveys are researches where the opinions, attitudes concerning one fact and incident are taken, aiming to describe facts and incidents (Karakaya, 2014).The study is a descriptive research designed as a crosssectional screening model. Cross-sectional screening model is a research method which the sample size is mostly large and involves different types of groups (Buyukozturk, Cakmak, Akgun, Karadeniz \& Demirel, 2014).

\section{Study Population and Sample Size}

The sample of the study comprises 180 social studies teacher candidates studying in the Social Studies Teaching Department, Faculty of Education of Ege University. The study population of the research consists of teacher candidates studying in the Social Studies Teaching Department, Faculty of Education of Ege University in the 2016-2017 academic year. It is believed that teacher candidates majoring in social studies will give more accurate answers to the research questions posed in the Digital Citizenship Attitude Scale thanks to their undergraduate education and because of their duty of citizenship transmission in their future teaching career. For this reason, the social studies teacher candidates were selected as a subject for the research. 
Table 1. The Frequency Distribution of the Variables in the Sample Group

\begin{tabular}{llcc}
\hline Variable & Categories & $\mathbf{N}$ & $\mathbf{\%}$ \\
\hline \multirow{2}{*}{ Gender } & Female & 113 & 62.70 \\
& Male & 67 & 37.24 \\
\hline \multirow{2}{*}{ Age } & $17-19$ years & 11 & 6.11 \\
& $20-22$ years & 112 & 62.25 \\
\hline \multirow{2}{*}{ Owning a personal computer } & 23 years and above & 57 & 31.66 \\
\hline \multirow{3}{*}{ Years of Experience in Computer Use } & Yes & 140 & 77.77 \\
& No & 40 & 22.23 \\
\hline & $0-2$ years & 15 & 8.33 \\
& 6-5 years & 28 & 15.57 \\
& 9 years and above & 43 & 23.88 \\
\hline
\end{tabular}

Disproportional sampling was administrated to the Faculty of Education in the study. The current study attempted to reach all social studies teacher candidates who participated in the study voluntarily.

\section{Data Collection Tools}

To accomplish the goal of the research, 63-item "Digital Citizenship Scale" developed by Kocadag (2012) was employed to identify the digital citizenship levels of social studies teacher candidates.

This scale was developed to evaluate teacher candidates' perceptions towards seeking and constructing information. However, the validity and reliability data of the scale were re-examined over the universe of this study. For this purpose, data were collected from other participants except the participants in this study and it was aimed to recalculate the Cronbach's alpha coefficient. Kaiser-Mayer-Olkin (KMO) test was conducted to identify the compatibility of the data obtained from the original 63 item-scale with factor analysis. As a result of the test, Kaiser-Meyer-Olkin (KMO) value was.976. This value is deemed "excellent" (Tabachnick \& Fidell, 2001). The items with factor loadings between the values of .328 and .862 were included to the study. Following the factor rotation process, the scale comprised 7 factors as follows: "Digital Communication and Literacy" with 24 items, "Digital Ethics and Law" with 16 items, " Digital Access" with 7 items and " Digital Rights and Responsibilities" with 3 items, "Digital Health" with 5 items, "Digital Security" with 5 items and "Digital Commerce " with 3 items. Cronbach's alpha reliability coefficient of the scale was found .97 (Kocadag, 2012).

Table 2. Reliability Coefficient of the Scale

\begin{tabular}{lcc}
\hline Scales & Reliability Coefficient & Item Numbers \\
\hline Digital Citizenship Scale (2012) & .97 & 63 \\
Subdimensions of the Digital Citizenship Scale & & \\
Digital Communication and Literacy & $\mathbf{. 9 6 7}$ & $\mathbf{2 4}$ \\
Digital Ethics and Law & $\mathbf{. 9 4 7}$ & $\mathbf{1 6}$ \\
Digital Access & $\mathbf{. 6 6 3}$ & $\mathbf{7}$ \\
Digital Rights and Responsibilities & $\mathbf{7 4 5}$ & $\mathbf{3}$ \\
Digital Healthy & $\mathbf{. 8 0 5}$ & $\mathbf{5}$ \\
Digital Security & $\mathbf{. 7 0 9}$ & $\mathbf{5}$ \\
Digital Commerce & $\mathbf{. 7 5 0}$ & $\mathbf{3}$ \\
\hline
\end{tabular}

In the literature, Cronbach's alpha coefficient values with 0.70 and above are considered acceptable for the reliability (Tezbasaran, 1996) we can thus contend that the instrument is a reliable and valid scale.

\section{Data Analysis}

In an attempt to identify digital citizenship levels of teacher candidates, the Kolmogorov-Smirnov test was performed to evaluate the normality of the variables. The distribution of the variables identified was evaluated and afterwards it was agreed on which parametric or non-parametric test would be applied. Lastly, alongside descriptive statistics, arithmetic mean and standard deviation was used to identify digital citizenship levels of the teacher candidates.

\section{Findings}

In attempt to seek answers to the sub problems posed in the study, a series of analyses conducted and findings of these analyses were presented in this section. The normality test was firstly applied to the variables identified in the study to find out how they were distributed. Skewness and Kurtosis Coefficients are presented in the Table 3 below and the normality of the data obtained was discussed. 
Table 3. Skewness and Kurtosis Coefficients of the Research Variable

\begin{tabular}{ccc}
\hline Variable & Kurtosis & Skewness \\
\hline Digital Citizenship Mean Score & 1.94 &,- 639 \\
\hline
\end{tabular}

From Table 3, we can see that the coefficients of skewness and kurtosis remain in the \pm 2 interval. According to George and Mallery (2016), the range for Kurtosis and Skewness between -2 and +2 is considered acceptable. However, Kurtosis and Skewness values are not enough to determine the normality. Therefore, Kolmogorov-Smirnov and Shapiro-Wilk tests are used to check the normality of the data. If the sample size is larger than 50, the KolmogorovSmirnov test results are taken into account (Yazicioglu \& Erdogan, 2007).

Table 4. K-S Test Applied to the Variables Identified

\begin{tabular}{|c|c|c|c|}
\hline \multicolumn{4}{|c|}{ Normality Test (Kolmogorov-Smirnov) } \\
\hline & Statistic & sd & $\mathbf{p}$ \\
\hline University & .059 & 180 & .200 \\
\hline
\end{tabular}

Based on the data shown in Table 4, digital citizenship scores indicate normal distribution as the significance level is $p>0.05$ according to the Kolmogorov-Smirnov (K-S) test results. When " $p$ " value is significant at $0.05(p<0.05)$, it means normal distribution and non-parametric tests need to be used. If the significance level is $p>0.05$, then parametric test is employed (Can, 2013). For this reason, parametric tests were used to identify the research findings.

The first sub- problem of the study seeks to answer the following question: 'Do digital citizenship levels of teacher candidates significantly differ by the gender variable?' In this sense, the results of t-test and test for homogeneity of variance will be examined before the analysis. The homogeneity of variance must be provided to run independent samples t-test (Tabachnick \& Fidell, 2001).

Table 5. Levene's Test for Homogeneity of Variance by the Gender Variable

\begin{tabular}{ccc}
\hline Digital Citizenship Mean Score & F & $\mathbf{p}$ \\
\hline Equivalence of Variances & .31 & .57 \\
\hline
\end{tabular}

Before running the independent samples t-test, as we see, the premises of homogeneity of variance were confirmed $(p=, 731 ; p>, 01)$ according to the Levene's test results presented in Table 5. Thus, the last premises of independent samples t-test were provided. The t-test was performed to figure out whether digital citizenship levels of the teacher candidates significantly differed according to the gender variable.

Table 6. $t$-test results of the Digital Citizenship Scale by the gender variable

\begin{tabular}{|c|c|c|c|c|c|c|c|}
\hline & Gender & $\mathbf{N}$ & $\overline{\mathbf{x}}$ & SD & df & $\mathbf{t}$ & $\mathbf{p}$ \\
\hline \multirow{2}{*}{$\begin{array}{l}\text { Digital Communication } \\
\text { Literacy }\end{array}$} & Female & 113 & 97.85 & 13.20 & \multirow{2}{*}{178} & \multirow{2}{*}{-.14} & \multirow{2}{*}{.88} \\
\hline & Male & 67 & 98.14 & 12.62 & & & \\
\hline \multirow{2}{*}{ Digital Ethics and Law } & Female & 113 & 66.24 & 8.47 & \multirow{2}{*}{178} & \multirow{2}{*}{2.59} & \multirow{2}{*}{.01} \\
\hline & Male & 67 & 63.01 & 7.38 & & & \\
\hline \multirow{2}{*}{ Digital Access } & Female & 113 & 27.80 & 4.67 & \multirow{2}{*}{178} & \multirow{2}{*}{-.78} & \multirow{2}{*}{.43} \\
\hline & Male & 67 & 28.35 & 4.31 & & & \\
\hline \multirow{2}{*}{$\begin{array}{l}\text { Digital Rights and } \\
\text { Responsibilities } \\
\end{array}$} & Female & 113 & 11.12 & 2.39 & \multirow{2}{*}{178} & \multirow{2}{*}{-.74} & \multirow{2}{*}{.46} \\
\hline & Male & 67 & 11.38 & 2.15 & & & \\
\hline \multirow{2}{*}{ Digital Healthy } & Female & 113 & 18.86 & 3.82 & \multirow{2}{*}{178} & \multirow{2}{*}{.18} & \multirow{2}{*}{.85} \\
\hline & Male & 67 & 18.76 & 3.61 & & & \\
\hline \multirow{2}{*}{ Digital Security } & Female & 113 & 21.17 & 6.24 & \multirow{2}{*}{178} & \multirow{2}{*}{1.13} & \multirow{2}{*}{.25} \\
\hline & Male & 67 & 20.25 & 3.00 & & & \\
\hline \multirow{2}{*}{ Digital Commerce } & Female & 113 & 12.11 & 2.59 & \multirow{2}{*}{178} & \multirow{2}{*}{.13} & \multirow{2}{*}{.89} \\
\hline & Male & 67 & 12.05 & 2.73 & & & \\
\hline \multirow{2}{*}{ Total } & Female & 113 & 255.19 & 31.74 & \multirow{2}{*}{178} & \multirow{2}{*}{.69} & \multirow{2}{*}{.49} \\
\hline & Male & 67 & 251.98 & 27.28 & & & \\
\hline
\end{tabular}

The significance levels obtained from the t-test are tabulated in Table 6 . In the context of the subdimensions of the study, it was examined whether the social studies teacher candidates significantly differed by the gender variable to figure out digital citizenship levels of social studies teacher candidates.

In this respect, it was found that the gender variable significantly differs only in the subdimension of "digital ethics and law" and has a significant effect over the digital citizenship levels of the social studies teacher candidates $(\mathrm{t}(178)=.2 .59$, $\mathrm{p}<.05, d=0.38$ ). However, the effect size of difference between two variables is low. Accordingly, the total raw scores of 
female teacher candidates in the sample group are found 66.24, whereas the total raw scores of male candidates are calculated as 63.01. We can thus infer that female teacher candidates have a higher level of digital citizenship in terms of the digital ethics and law. No significant difference were observed in the total digital citizenship levels $(t(178)=.69$, $\mathrm{p}>.05)$ and other subdimensions ( $\mathrm{p}>.05)$ in terms of the gender variable.

As a conclusion, given that the fundamental objective of the study was to explore the digital citizenship levels of teacher candidates, it was seen that no meaningful differences were detected in the total scores with respect to the gender variable. Yet, it is quite a striking finding that the gender variable has a significant effect at the.05 level only in the subdimension of digital ethics and law in the scale.

The second sub-problem of the research seeks to the following question 'Do digital citizenship levels of teacher candidates significantly differ by the variable of owning a personal computer?' Prior to the analysis of the t- test, the test results of the homogeneity off variance will be checked. The homogeneity of variance must be provided to run independent samples t-test (Tabachnick \& Fidell, 2001).

Table 7.Levene's Test for Homogeneity of Variance

\begin{tabular}{ccc}
\hline Digital Citizenship Mean Score & $\mathbf{F}$ & $\mathbf{p}$ \\
\hline Equivalence of Variances & .05 & .82 \\
\hline
\end{tabular}

Before running independent samples t-test, as the Levene's test results presented in Table 7, the premises of homogeneity of variance were confirmed $(\mathrm{p}=.82 ; \mathrm{p}>.01)$. Thus, the last premises of independent samples t-test were provided. T-test was conducted to see whether digital citizenship levels of the teacher candidates significantly differed by the variable of owning a personal computer.

As shown in Table 8, the social studies teacher candidates owning a personal computer has a significant effect on the total levels of the Digital Citizenship Scale $(\mathrm{t}(178)=.4 .26, \mathrm{p}<.05)$. Correspondingly, the total raw scores of the teacher candidates owning a personal computer in the sample group are found 258.89 , whereas the total raw scores of the social studies candidates who do not own a personal computer are calculated as 236.87 . When viewing the effect of the variable of owning a personal computer on digital citizenship levels in the context of subdimension, we see that there is a significant difference in the subdimension of "digital communication and literacy" $(\mathrm{t}(178)=4.36, \mathrm{p}<.05, d=0.82)$. When the effect size of this difference is evaluated, it is seen that this difference is large. Besides that, it is quite interesting that there are meaningful differences in the digital citizenship levels of the subdimension of "digital ethics and law" $(\mathrm{t}(178)=2.86, \mathrm{p}<.05, d=0.54)$. When the effect size of the difference is evaluated, it is seen that this difference is middle. Additionally, there is a meaningful difference in the digital citizenship levels of the social studies teacher candidates with respect to the subdimension of "digital access" $(\mathrm{t}(178)=3.91, \mathrm{p}<.05, d=0.74)$. When the effect size of the difference is evaluated, it is seen that this difference is middle. Moreover, we also see significant difference in the subdimension of "digital rights and responsibilities" $(\mathrm{t}(178)=2.92, \mathrm{p}<.05, d=0.55)$. When the effect size of the difference is evaluated, it is seen that this difference is middle. Lastly, significant difference was found in the digital citizenship levels of teacher candidates as regards the subdimension of "digital health" $(\mathrm{t}(178)=2.43, \mathrm{p}<.05, d=0.46)$ in favor of those owning a personal computer. When the effect size of the difference is evaluated, it is seen that this difference is low.

Table 8. T-test results of the Digital Citizenship Scale by the Variable of Owning a Personal Computer

\begin{tabular}{|c|c|c|c|c|c|c|c|}
\hline & $\begin{array}{l}\text { Owning a } \\
\text { personal } \\
\text { computer }\end{array}$ & $\mathbf{N}$ & $\mathbf{X}$ & SD & df & $\mathbf{t}$ & $\mathbf{p}$ \\
\hline \multirow{2}{*}{$\begin{array}{l}\text { Digital Communication } \\
\text { Literacy }\end{array}$} & Yes & 140 & 100.11 & 11.79 & 178 & 4.36 & .00 \\
\hline & No & 40 & 90.45 & 14.14 & & & \\
\hline \multirow{2}{*}{ Digital Ethics and Law } & Yes & 140 & 65.96 & 7.83 & 178 & 2.86 & .00 \\
\hline & No & 40 & 61.82 & 8.76 & & & \\
\hline \multirow{2}{*}{ Digital Access } & Yes & 140 & 28.96 & 4.34 & 178 & 3.91 & .00 \\
\hline & No & 40 & 25.62 & 4.46 & & & \\
\hline \multirow{2}{*}{$\begin{array}{l}\text { Digital Rights and } \\
\text { Responsibilities }\end{array}$} & Yes & 140 & 11.48 & 2.29 & 178 & 2.92 & .00 \\
\hline & No & 40 & 10.30 & 2.13 & & & \\
\hline \multirow{2}{*}{ Digital Healthy } & Yes & 140 & 19.18 & 3.61 & 178 & 2.43 & .01 \\
\hline & No & 40 & 17.57 & 3.93 & & & \\
\hline \multirow{2}{*}{ Digital Security } & Yes & 140 & 21.16 & 5.72 & 178 & 1.57 & .11 \\
\hline & No & 40 & 19.67 & 3.11 & & & \\
\hline \multirow{2}{*}{ Digital Commerce } & Yes & 140 & 12.28 & 2.38 & 178 & 1.83 & .06 \\
\hline & No & 40 & 11.42 & 3.33 & & & \\
\hline \multirow{2}{*}{ Total Score } & Yes & 140 & 258.89 & 27.92 & 178 & 4.26 & .00 \\
\hline & No & 40 & 236.87 & 31.61 & & & \\
\hline
\end{tabular}


Consequentially, we can contend that there are significant differences in the total scores and other subdimensions, namely, digital communication and literacy, digital ethics and law, digital access, digital rights and responsibilities, and digital health according to the variable of owning a personal computer. Surprisingly, the variable of owning a personal computer produces no significant effect at the .05 level on the subdimensions of digital security and digital commerce.

The third subproblem of the research seeks to the following question: "Do digital citizenship levels of teacher candidates significantly differ by the age variable?" Prior to one-way Anova test to be conducted, the results of test for homogeneity of variances will be examined. The homogeneity of variance must be provided to run the one-way Anova test (Tabachnick \& Fidell, 2001).

Table 9.Levene Test for Homogeneity of Variance by the Age Variable

\begin{tabular}{ccc}
\hline Digital Citizenship Mean Score & F & p \\
\hline Equivalence of Variances & 4.94 & .02 \\
\hline
\end{tabular}

The Levene's test results stated in Table 9 indicate that variances are not homogenous prior to the one-way ANOVA analysis $(p=4.94 ; p>.01)$. For this reason, non-homogenous differentiation analysis can be used during the process of one-way ANOVA analysis. One-way ANOVA analysis was applied to see if social studies teacher candidates' digital citizenship scores significantly differed according to the age variable.

According to the findings in Table 10, there is a statistically significant difference in the total digital citizenship score of the social studies teacher candidates in terms of the age variable $\left(F(2,177)=3.63, p<.05, \eta^{2}=.05\right)$. In other words, digital citizenship score levels of the social studies teacher candidates in the sample are not equal with each other according to the age variable. Besides that, with respect to the subdimensions in the scale, we can contend that there are meaningful differences in the subscale of "digital communication and literacy" $\left(F(2,177)=4.50, p<.05, \eta^{2}=.05\right)$. Similarly, there are significant differences in the subscale of "Digital Ethics and Law" $\left(F(2,177)=4.10, p<.05, \eta^{2}=.04\right)$. However, all of these differences' effect size is low. Therefore, Dunnett's Multiple Comparison test were employed to identify significant differences between the groups. Dunnett $\mathrm{C}$ is one of the multicomparision tests which can be applied using average mean scores in non-parametric distributions, that is to say, where the variances are equal and the $\mathrm{q}$ distribution is used in Tukey's test (Buyukozturk, 2004).

Table 10. ANOVA test results regarding the digital citizenship scores according to teacher candidates' age ranges

\begin{tabular}{|c|c|c|c|c|c|c|}
\hline Subdimension & Source of Variance & Sum of Square & df & Mean of Square & $\mathbf{F}$ & $\mathbf{p}$ \\
\hline Digital & Between Groups & 1486.23 & 2 & 743.11 & & \\
\hline Communication & Within Groups & 28551.56 & 177 & 161.30 & 4.50 & .01 \\
\hline Literacy & Total & 30037.80 & 179 & & & \\
\hline \multirow{3}{*}{$\begin{array}{l}\text { Digital Ethics and } \\
\text { Law }\end{array}$} & Between Groups & 534.80 & 2 & 267.40 & \multirow{3}{*}{4.10} & \multirow{3}{*}{.01} \\
\hline & Within Groups & 11534.84 & 177 & 65.16 & & \\
\hline & Total & 12069.64 & 179 & & & \\
\hline \multirow{3}{*}{ Digital Access } & Between Groups & 115.58 & 2 & 57.79 & \multirow{3}{*}{2.86} & \multirow{3}{*}{.06} \\
\hline & Within Groups & 3576.39 & 177 & 20.20 & & \\
\hline & Total & 3691.97 & 179 & & & \\
\hline \multirow{3}{*}{$\begin{array}{l}\text { Digital Rights and } \\
\text { Responsibilities }\end{array}$} & Between Groups & 7.22 & 2 & 3.61 & \multirow{3}{*}{.67} & \multirow{3}{*}{.51} \\
\hline & Within Groups & 947.88 & 177 & 5.35 & & \\
\hline & Total & 955.11 & 179 & & & \\
\hline \multirow{3}{*}{ Digital Health } & Between Groups & 29.49 & 2 & 14.74 & \multirow{3}{*}{1.05} & \multirow{3}{*}{.35} \\
\hline & Within Groups & 2476.16 & 177 & 13.99 & & \\
\hline & Total & 2505.66 & 179 & & & \\
\hline \multirow{3}{*}{ Digital Security } & Between Groups & 5.00 & 2 & 2.50 & \multirow{3}{*}{.08} & \multirow{3}{*}{.91} \\
\hline & Within Groups & 4991.99 & 177 & 28.20 & & \\
\hline & Total & 4997.00 & 179 & & & \\
\hline \multirow{3}{*}{ Digital Commerce } & Between Groups & 18.13 & 2 & 9.06 & \multirow{3}{*}{1.30} & \multirow{3}{*}{.27} \\
\hline & Within Groups & 1227.26 & 177 & 6.93 & & \\
\hline & Total & 1245.39 & 179 & & & \\
\hline \multirow{3}{*}{$\begin{array}{l}\text { Total } \\
\text { Score }\end{array}$} & Between Groups & 6402.25 & 2 & 3201.12 & \multirow{3}{*}{3.63} & \multirow{3}{*}{.02} \\
\hline & Within Groups & 156057.75 & 177 & 881.68 & & \\
\hline & Total & 162460.00 & 179 & & & \\
\hline
\end{tabular}

${ }^{*} p<.05$ Age Ranges (1=17-19 years; $2=20$-22 years; $3=23$ years and above)

According to the age variable of teacher candidates, Dunnett-C test results regarding the differences within the groups are presented in Table 11. 
Considering the results of Dunnett-C test given in Table 11, there is a significant difference between the digital citizenship scores of the social studies teacher candidates aged 20-22 and the social studies teacher candidates aged 17-19 and 23 years and above in favor of the social studies teacher candidates aged 20-22 $\left(F_{(177)}=3.63, p<.05\right)$. Additionally, with respect to the "digital communication and literacy" subdimension, it is seen that there is a meaningful difference between the digital citizenship scores of participants in the 20-22 age group and the participants aged 17-19 in favor of the participants in the 20-22 age group. $(\mathrm{F}(177)=4.50, \mathrm{p}<.05)$.

Table 11. Dunnett-C Test Results of the Social Studies Teacher Candidates by the Age Variable

\begin{tabular}{|c|c|c|c|c|c|c|}
\hline \multicolumn{7}{|c|}{ Reliability Range of $95 \%$} \\
\hline Subdimension & Age & AgeMean & Std Error & Below & LimitUpper & DifferenceLimit \\
\hline \multirow{6}{*}{$\begin{array}{l}\text { Digital Communication } \\
\text { Literacy }\end{array}$} & \multirow{2}{*}{ 17-19 years } & 20-22 years & $-10.37^{*}$ & 6.24 & -27.43 & 6.68 \\
\hline & & 23- + years & -6.20 & 6.42 & -23.63 & 11.21 \\
\hline & \multirow{2}{*}{ 20-22 years } & 17-19 years & $10.37^{*}$ & 6.24 & -6.68 & 27.43 \\
\hline & & $23-+$ years & 4.16 & 2.10 & -.87 & 9.20 \\
\hline & \multirow{2}{*}{$23-+$ above } & 17-19 years & 6.20 & 6.42 & -11.21 & 23.63 \\
\hline & & 20-22 years & -4.16 & 2.10 & -9.20 & .87 \\
\hline \multirow{6}{*}{ Digital Ethics and Law } & \multirow{2}{*}{ 17-19 years } & 20-22 years & $-4.98^{*}$ & 3.74 & -15.20 & 5.23 \\
\hline & & $23-+$ years & -1.82 & 3.88 & -12.34 & 8.69 \\
\hline & \multirow{2}{*}{ 20-22 years } & 17-19 years & 4.98 & 3.74 & -5.23 & 15.20 \\
\hline & & $23-+$ years & 3.15 & 1.38 & -.17 & 6.48 \\
\hline & \multirow{2}{*}{$23-+$ above } & $17-19$ years & 1.82 & 3.74 & -8.69 & 12.34 \\
\hline & & 20-22 years & -3.15 & 1.38 & -6.48 & .17 \\
\hline \multirow{6}{*}{ Total Score } & \multirow[t]{2}{*}{$17-19$ years } & 20-22 years & $-22.79 *$ & 14.29 & -61.85 & 16.26 \\
\hline & & $23-+$ above & $-15.21^{*}$ & 14.83 & -55.39 & 24.97 \\
\hline & \multirow[t]{2}{*}{ 20-22 years } & 17-19 years & $22.79 *$ & 14.29 & -16.26 & 61.85 \\
\hline & & $23-+$ above & 7.58 & 5.13 & -4.74 & 19.91 \\
\hline & \multirow[t]{2}{*}{$23-+$ above } & 17-19 years & $15.21 *$ & 14.83 & -24.97 & 55.39 \\
\hline & & 20-22 years & -7.58 & 5.13 & -19.91 & 4.74 \\
\hline
\end{tabular}

On the other hand, as for the "digital ethics and law" subdimension, significant difference was found between the digital citizenship scores of the participants in the 20-22 age range and the participants aged 17-19. This difference is in favor of the participants in the $20-22$ age range $(F(177)=4.10, p<.05)$. In light of the data obtained, it is seen that digital citizenship scores of the social studies teacher candidates in the 20-22 age range are higher than those candidates aged 17-19. When analyzing the Table 11, it is seen that there is not another significant differences between age groups about digital ethics and law subdimension.

When it comes to the final sub-problem, the research seeks to answer the following question: 'Do digital citizenship levels of the teacher candidates significantly differ by the variable of years of experience in computer use?'. The mean and standard deviations of the four groups formed according to the duration of computer use showed Table 11.

Table 12. Mean and Standard Deviation of groups formed by experience in computer use

\begin{tabular}{lcccr}
\hline Groups & N & X & S & Range \\
\hline Group 1 (0-2 years) & 15 & 234.33 & 39.85 & 51 \\
\hline Group 2 (3-5 years) & 28 & 246.11 & 28.15 & 115 \\
\hline Group 3 (6-8 years) & 43 & 261.26 & 23.42 & 105 \\
\hline Group 4 (9+ years) & 94 & 256.17 & 30.33 & 151 \\
\hline
\end{tabular}

Prior to one-way Anova test to be conducted, the results of test for homogeneity of variances will be examined. The homogeneity of variance must be provided to run the one-way Anova test (Tabachnick \& Fidell, 2001).

Table 13. Levene Test for Homogeneity of Variance by the variable of Years of experience in computer use

\begin{tabular}{ccc}
\hline Digital Citizenship Mean Score & $\mathbf{F}$ & $\mathbf{p}$ \\
\hline Equivalence of Variances & 1.06 & .36 \\
\hline
\end{tabular}

Before proceeding to one-way Anova analysis, as the Levene's test results presented in Table 13, the premises of homogeneity of variance were confirmed $(p=1.06 ; p>.01)$. Thus, the last premises of one-way ANOVA analysis were met. The one-way ANOVA was utilized to determine whether digital citizenship scores of the social studies teacher candidates differentiated according to the variable of years of experience in computer use. 
Table 14. Anova Results of the Digital Citizenship of the Teacher Candidates by the Variable of Years of experience in computer use

\begin{tabular}{|c|c|c|c|c|c|c|}
\hline Subdimension & Source of Variance & Sum of Square & df & Mean of Square & $\mathbf{F}$ & $\mathbf{p}$ \\
\hline Digital & Between Groups & 2515.92 & 3 & 838.64 & & \\
\hline Communication & Within Groups & 27521.88 & 176 & 156.37 & 5.36 & .00 \\
\hline Literacy & Total & 30037.80 & 179 & & & \\
\hline \multirow{3}{*}{$\begin{array}{l}\text { Digital Ethics and } \\
\text { Law }\end{array}$} & Between Groups & 479.78 & 3 & 159.92 & \multirow{3}{*}{2.42} & \multirow{3}{*}{.06} \\
\hline & Within Groups & 11589.85 & 176 & 65.85 & & \\
\hline & Total & 12069.64 & 179 & & & \\
\hline \multirow{3}{*}{ Digital Access } & Between Groups & 205.07 & 3 & 68.36 & \multirow{3}{*}{3.45} & \multirow{3}{*}{.01} \\
\hline & Within Groups & 3486.89 & 176 & 19.81 & & \\
\hline & Total & 3691.97 & 179 & & & \\
\hline \multirow{3}{*}{$\begin{array}{l}\text { Digital Rights and } \\
\text { Responsibilities }\end{array}$} & Between Groups & 14.24 & 3 & 4.74 & \multirow{3}{*}{.88} & \multirow{3}{*}{.44} \\
\hline & Within Groups & 940.87 & 176 & 5.34 & & \\
\hline & Total & 955.11 & 179 & & & \\
\hline \multirow{3}{*}{ Digital Health } & Between Groups & 15.97 & 3 & 5.32 & \multirow{3}{*}{.37} & \multirow{3}{*}{.77} \\
\hline & Within Groups & 2489.68 & 176 & 14.14 & & \\
\hline & Total & 2505.66 & 179 & & & \\
\hline \multirow{3}{*}{ Digital Security } & Between Groups & 186.44 & 3 & 62.14 & \multirow{3}{*}{2.27} & \multirow{3}{*}{.08} \\
\hline & Within Groups & 4810.55 & 176 & 27.33 & & \\
\hline & Total & 4997.00 & 179 & & & \\
\hline \multirow{3}{*}{ Digital Commerce } & Between Groups & 41.15 & 3 & 13.71 & \multirow{3}{*}{2.00} & \multirow{3}{*}{.11} \\
\hline & Within Groups & 1204.24 & 176 & 6.84 & & \\
\hline & Total & 1245.39 & 179 & & & \\
\hline \multirow{3}{*}{$\begin{array}{l}\text { Total } \\
\text { Score }\end{array}$} & Between Groups & 10252.52 & 3 & 3417.50 & \multirow{3}{*}{3.95} & \multirow{3}{*}{.00} \\
\hline & Within Groups & 152207.47 & 176 & 864.81 & & \\
\hline & Total & 162460.00 & 179 & & & \\
\hline
\end{tabular}

*p $<.05$ years of experience in computer use( $1=0-2$ years; $2=3-5$ years; $3=6-8$ years; $4=9$ years + above)

According to the data in Table 14, there is a statistically significant difference in the total digital citizenship scores of the social studies teacher candidates in terms of the variable of years of experience in computer use $(F(3,176)=3.95$, $\mathrm{p}<.05)$. In other words, digital citizenship levels of the social studies teacher candidates in the sample differentiate according to the years of experience in computer use. Besides that, with respect to the subdimensions in the scale, we can contend that there are meaningful differences in the subscale of "digital communication and literacy" $(\mathrm{F}(3,176)=$ $\left.5.36, \mathrm{p}<.05, \eta^{2}=.08\right)$. The effect size of this differences is large. Similarly, there are significant differences in the subscale of "Digital Access" $\left(F(2,177)=3.45, p<.05, \eta^{2}=.06\right)$. However, the effect size of this differences is middle. Therefore, Tukey's multiple comparison test was run to identify significant differences between the groups. Tukey is one of the multicomparision tests which can be applied using average mean scores in non-parametric distributions, that is to say, where the variances are equal and the q distribution is used in Tukey's test (Buyukozturk, 2004).

According to the variable of years of experience in computer use, the Tukey's test results regarding the differences within the groups are tabulated in Table 15. The results of Tukey's test presented in Table 15 demonstrate that there is a significant difference between the digital citizenship scores of the social studies teacher candidates with $0-2$ years of experience in computer use and those with 6-8 and 9 years and above in favor of the latter one $\left(F(177)=3.95, p<.05, \eta^{2}\right.$ $=.06$. However, the effect size of this differences is middle. 
Table 15. Tukey Test Results Related to the Variable of Years of Experience in Computer Use of The social studies teacher candidates

\begin{tabular}{|c|c|c|c|c|c|c|}
\hline \multicolumn{7}{|c|}{ Reliability Range of $95 \%$} \\
\hline \multirow[t]{2}{*}{ Subdimension } & \multirow[t]{2}{*}{ Age } & Age Mean $S$ & Std Error & Lower & \multicolumn{2}{|c|}{ Limit Upper Difference Limit } \\
\hline & & $3-5$ years & -5.23 & 4.00 & -15.61 & 5.14 \\
\hline \multirow{11}{*}{$\begin{array}{l}\text { Digital Communication } \\
\text { Literacy }\end{array}$} & \multirow[t]{2}{*}{$0-2$ years } & 6-8 years & $-11.24^{*}$ & 3.74 & -20.97 & -1.51 \\
\hline & & 9 years+ above & $-11.87^{*}$ & 3.47 & -20.88 & -2.85 \\
\hline & \multirow{3}{*}{$3-5$ years } & 0-2 years & 5.23 & 4.00 & -5.14 & 15.61 \\
\hline & & 6-8 years & -6.01 & 3.03 & -13.88 & 1.86 \\
\hline & & 9 years+ above & -6.63 & 3.69 & -13.62 & .34 \\
\hline & \multirow{4}{*}{$6-8$ years } & 0-2 years & $11.24^{*}$ & 3.74 & 1.51 & 20.97 \\
\hline & & 3-5 years & 6.01 & 3.03 & -1.86 & 13.88 \\
\hline & & 9 years+ above & -.62 & 2.30 & -6.59 & 5.34 \\
\hline & & 0-2 years & $11.87^{*}$ & 3.47 & 2.85 & 20.88 \\
\hline & \multirow[t]{2}{*}{9 years + above } & 3-5 years & 6.63 & 2.69 & -.34 & 13.62 \\
\hline & & 6-8 years & .62 & 2.30 & -5.34 & 5.34 \\
\hline \multirow{12}{*}{ Digital Access } & \multirow{3}{*}{$0-2$ years } & 3-5 years & -1.86 & 1.42 & -5.55 & 1.83 \\
\hline & & 6-8 years & $-3.65^{*}$ & 1.33 & -7.11 & -.19 \\
\hline & & 9 years+ above & $-3.41 *$ & 1.23 & -6.62 & -.20 \\
\hline & \multirow{3}{*}{ 3-5 years } & 0-2 years & 1.86 & 1.42 & -1.83 & 5.55 \\
\hline & & 6-8 years & -1.79 & 1.08 & -4.59 & 1.01 \\
\hline & & 9 years + above & -1.55 & .95 & -4.03 & .93 \\
\hline & \multirow{4}{*}{$6-8$ years } & 0-2 years & $3.65^{*}$ & 1.33 & .19 & 7.11 \\
\hline & & 3-5 years & 1.79 & 1.08 & -1.01 & 4.59 \\
\hline & & 9 years+ above & .24 & .81 & -1.88 & 2.36 \\
\hline & & 0-2 years & $3.41^{*}$ & 1.23 & .20 & 6.62 \\
\hline & \multirow[t]{2}{*}{9 years + above } & 3-5 years & 1.55 & .95 & -.93 & 4.03 \\
\hline & & 6-8 years & -.24 & .81 & -2.36 & 1.89 \\
\hline \multirow{12}{*}{ Total Score } & \multirow{4}{*}{$0-2$ years } & 3-5 years & -11.77 & 9.40 & -36.17 & 12.63 \\
\hline & & 6-8 years & $-26.92 *$ & 8.81 & -49.79 & -4.04 \\
\hline & & 9 years+ above & $-21.83^{*}$ & 8.17 & -43.04 & -.62 \\
\hline & & 0-2 years & 11.77 & 9.40 & -12.63 & 36.17 \\
\hline & \multirow[t]{3}{*}{$3-5$ years } & 6-8 years & -15.14 & 7.14 & -3.67 & 3.37 \\
\hline & & 9 years + above & -10.06 & 6.33 & -26.48 & 6.35 \\
\hline & & 0-2 years & $26.92^{*}$ & 8.81 & 4.04 & 49.79 \\
\hline & \multirow[t]{3}{*}{$6-8$ years } & 3-5 years & 15.14 & 7.14 & -3.37 & 33.67 \\
\hline & & 9 years+ above & 5.08 & 5.41 & -8.95 & 19.12 \\
\hline & & 0-2 years & $21.83^{*}$ & 8.17 & .62 & 43.04 \\
\hline & \multirow[t]{2}{*}{9 years + above } & 3-5 years & 10.06 & 6.33 & -6.35 & 26.48 \\
\hline & & 6-8 years & -5.08 & 5.41 & -19.12 & 8.95 \\
\hline
\end{tabular}

In addition to that, considering the subdimension " digital communication and literacy" it is resulted in that there is a meaningful difference between the social studies teacher candidates with 0-2 years of experience in computer use and those with 6-8 years and 9 years and above of experience in computer use experience. This difference is in favor of social studies teachers with $0-2$ years $(F(177)=5.36, p<.05)$. On the other hand, it was detected in the subscale of " digital access" that there are significant differences between the digital citizenship scores of participants with 0-2 years of computer experience and those with computer experience of 6-8 years and 9 and above in favor of those with 0-2 years of experience $(F(177)=3.45, p<.05)$. In this sense, we can conclude that digital citizenship scores of the social studies teacher candidates with 0-2 years of experience in computer use are higher than those social studies teacher candidates with 6-8 years and 9 years and above.

\section{Discussion and Recommendations}

The current study examined whether digital citizenship levels of the social studies teacher candidates significantly differed according to the various variables identified. In this respect, it was understood that the gender variable did not have a significant effect on total scores of digital citizenship. However, it is a striking result that the "digital ethics and law" subdimension of the scale significantly differed at the level of .05 by gender variable in favor of female teacher candidates.

Since the 1990s, citizenship studies have become institutionalized under the influence of postmodernism and globalization and the concept of citizenship has been redefined in various fields and correspondingly such new 
disciplines like gender-oriented citizenship, environmental citizenship, cultural citizenship, global citizenship and multicultural citizenship have taken their places in the literature (Isin \& Turner, 2002). In other studies by Isman and Gungoren (2013) and Bardakci, Akyuz, Samsa-Yetik and Keser (2014), Sakalli and Ciftci (2016), no significant difference was observed in terms of the gender variable. We can thus argue that these studies confirm the results of the present study with respect to the gender variable. On the other hand, it is an interesting result that there is a significant difference in favor of females in the subdimension of "digital ethics and law" of the scale. Ribble and Bailey (2007) postulate that digital ethics include electronic standards of behavior and procedure. Sharing illegal posts, writing offensive and insulting things about individuals or communities and etc. can be evaluated as unethical behaviors. The underlying reason that female teacher candidates had higher levels of digital citizenship in the subdimension of digital ethics and law compared to males is because of the gender-oriented approach adopted by the society.

It was observed that the social studies teacher candidates owning a personal computer indicated a meaningful difference regarding the total levels of digital citizenship scale. On the other hand, whether individuals are equipped with certain computer skills and own a personal computer depends on their economic conditions. In the similar vein, the literature reveals that citizens who lack internet access cannot effectively use digital tools (Oyedemi, 2012). According to Alkan (1984), technological changes have impacted education in terms of cultivating digital skills in individuals, raising digitally skilled workforce and utilizing technological opportunities. In their studies, Cepni, Oguz and Kilcan, (2014) and Vural and Kurt (2018) found a significant difference between digital citizenship levels of the teacher candidates in terms of the variable of owning a personal computer which supports the findings of the current study.

In today's society, the numbers of individuals who actively use Internet in their daily lives are quite high. The increasing number of Internet users can give us a hint about the digital citizenship by age groups. According to the data provided by Turkish Statistical Institute (TUIK) in 2011, the rate of internet usage by age groups is presented in the Figure 1 below (TUIK, 2011):

Figure 1 demonstrates that individuals in the 16-34 age group, in particular, are all active Internet users. Given that the 16-24 age group in our society shows a higher rate of internet usage, it might also have an influence over the digital citizenship levels of the teacher candidates in the 16-24 age group. The current study also indicated that there was statistically significant difference in total digital citizenship scores of the social studies teacher candidates according to the age variable. Also, Kocadag (2012) observed significant difference in terms of the age variable in his study. Given that the teacher candidates in the 20 -22 age range have a higher level of digital citizenship, we can argue that the education faculty programme of the teacher candidates has had a positive impact their digital competencies.

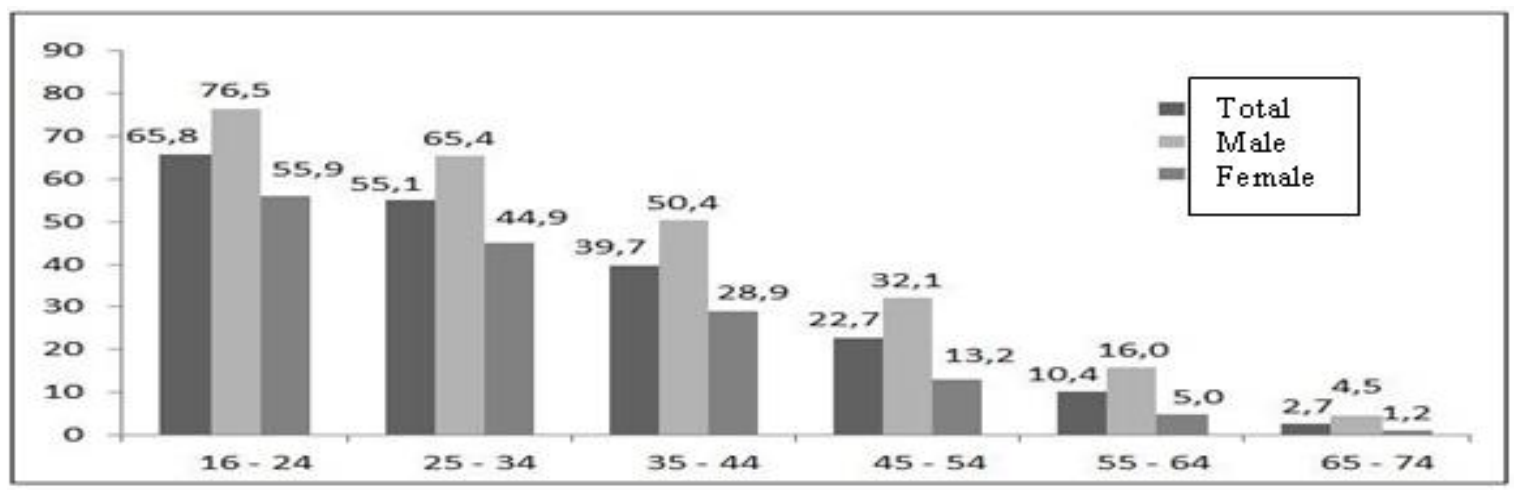

Figure. 1. According to TUIK data, the rate and percentage of Internet usage by age groups

With the rapid pace of technology, years of experience in computer use can be directly associated with internet access and internet usage. According to the data provided by TUIK in 2017, the percentages of the internet access, computer and internet usage are given in Figure 2. (TUIK, 2017). 

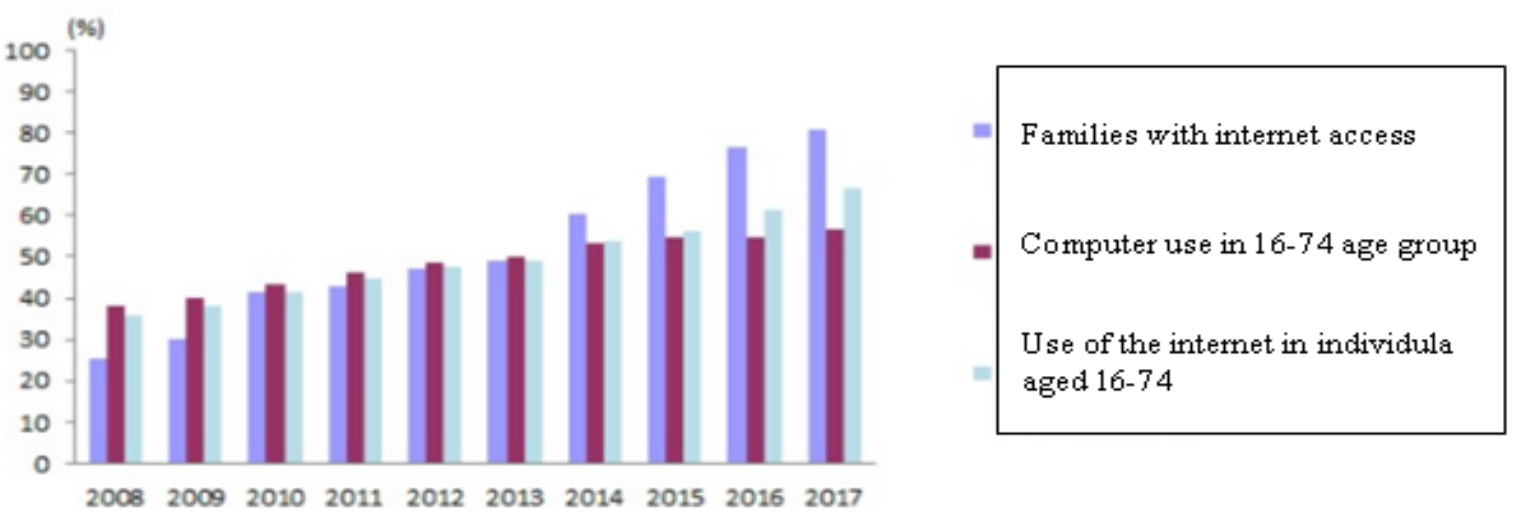

Figure. 2. According to TUIK data, the percentage of internet access, computer and internet usage

Figure 2 illustrates that according to the results of Information and Communication Technology Usage Survey in Turkish Households carried out in April, 2017, 80.7 percent of households have access to the Internet, whereas the percent of households who have access to the Internet was 76.3 in 2016 . This increase on computer and internet access by years has a direct link with the digital citizenship competences. Vural and Kurt (2018) assert that individuals' experiences will improve by their grade levels and accordingly the number of digital individuals who develop and adapt to change day by day will also increase. As a result, the individuals' interest to digital citizenship will grow as well.

It was observed that there is a statistically significant difference in total digital citizenship scores of the social studies teacher candidates in terms of the years of experience in computer use. Especially, the teacher candidates with a higher level of computer experience exhibit a higher level of digital citizenship. The findings obtained from the current study indicate similar results with Kocadag's (2012) research which suggests that individuals have a higher level of digital citizenship when their years of experience in computer use increase.

Given that the world is shrinking and we live in a highly globalized world, we should comply with the standards needed to assess students' knowledge and skills, thereby allowing students to experience a productive life and efficient learning. From this perspective, it is suggested that necessary steps must be taken to reduce disadvantageous conditions, where possible, among students in terms of the digital citizenship education.

The sample group comprises only social studies teacher candidates. For future studies, it would be useful to include other samples as well. Besides that, making comparison between groups will be more helpful in terms of the reflection of the population.

According to this research results, there was some suggestions about educational settings and applications. Firstly, at primary and secondary level, elective courses on digital literacy should be included. At the same time, while developing multi-literacy with an interdisciplinary perspective in other courses, digital and virtual tools which are a necessity of the society we live in should be used in different courses. Secondly, in secondary school, especially in courses with social studies and derivatives, programs should be reviewed and digital literacy related activities and departments should be added. Third and lastly, it is necessary that teachers working in schools receive in-service training on digital literacy and necessary arrangements are made in order to develop positive attitudes.

\section{References}

Alberta, E. (2012). Digital citizenship policy development guide. Edmonton, Canada: Alberta Education School Technology Branch.

Alkan, C. (1984). Educational technology: Concept, scope, process, environment, application. Ankara, Turkey: Stage.

Aslan, S. (2016). Ilkogretim sosyal bilgiler ogretmen adaylarinin dijital vatandaslik davranislarinin bazi degiskenler acisindan incelenmesi (Firat, Dicle, Siirt, Adiyaman Universiteleri ornegi) [Digital citizenship behaviour of social studies teachers of primary investigation of some variables (The sample of Firat, Dicle, Siirt, Adiyaman universities)] (Unpublished master's thesis). Firat University, Elazig, Turkey.

Bakir, E. (2016). Sinif ogretmeni adaylarinin dijital vatandaslik seviyelerinin dijital vatandaslik alt boyutlarina gore incelenmesi [Examining the digital citizenship levels of prospective classroom teachers according to the subdimensions of digital citizenship] (Unpublished master's thesis). Karadeniz Technical University , Trabzon, Turkey.

Barr, R., Barth, J. L. \& Shermis, S. S. (1978). The nature of the social studies. Palm Spring, CA: ETC.

Barth, F. (1998). Ethnic groups and boundaries: The social organization of culture difference. Waveland Press. 
Buyukozturk S. (2004). Sosyal bilimler icin veri analizi el kitabi [Data analysis handbook in social sciences]. Ankara, Turkey: Pegem Publishing.

Buyukozturk, S., Cakmak, E. K., Akgun, O. E., Karadeniz, S., \& Demirel, F. (2017). Bilimsel arastirma yontemleri [Methods of scientific research]. Ankara, Turkey: Pegem Publishing.

Can, A. (2013). SPSS ile bilimsel arastirma suresince nicel veri analizi [Quantitative data analysis in the process of scientific research with SPSS]. Ankara, Turkey: Pegem Publishing.

Castells, M. (2000). Materials for an exploratory theory of the network society. British Journal of Sociology, 5-24.

Isin, E. F. \& Turner, B. S. (2002). Citizenship studies: An introduction. London, England: Sage.

Karakaya, I. (2014). Bilimsel arastirma yontemleri [Scientific research methods]. In A. Tanriogen (Ed.), Bilimsel arastirma yontemleri [Scientific research methods] (pp. 57-86). Ankara, Turkey: Ani Publishing.

Kilinc, E. (2015). Elementary school and social studies teachers' opinions about the concept of good citizenship. Route Educational and Social Science Journal, 194-206.

Kocadag, T. (2012). Ogretmen adaylarinin dijital vatandaslik duzeylerinin belirlenmesi [Determining the digital citizenship levels of prospective teachers] (Unpublished master's thesis). Karadeniz Technical University, Trabzon, Turkey.

Ministry of National Education (2018). Social studies curriculum. Retrieved from http://mufredat.meb.gov.tr /Dosyalar/201812103847686SOSYAL\%20B\%C4\%B0LG\%C4\%B0LER\%20\%C3\%96\%C4\%9ERET\%C4\% B0M\%20PROGRAMI\%20.pdf

Mossberger, K., Tolbert, C. J., \& Mc. Neal, R. S. (2007). Digital citizenship: The internet, society and participation. London, England: The MIT Press.

Oyedemi, T. D. (2012). Digital inequalities and implications for social inequalities. Telematic and Informatic, 29(3), 302 -313. doi:10.1016/j.tele.2011.12.001.

Prensky, M. (2001). Digital natives, digital immigrants. On the Horizon, 9(5), 1-6.

Ribble, M. (2011). Digital citizenship in schools. Washington DC, USA: The International Society for Technology in Education.

Ribble, M., \& Bailey, G. (2007). Digital citizenship in schools. Washington, DC: ISTE.

Sakalli, H., \& Ciftci, S. (2016). Sinif ogretmeni adaylarinin dijital vatandaslik duzeyleri ile siber zorbalik egilimleri arasindaki iliskinin incelenmesi [The investigation of the relationship between digital citizenship levels and cyber bullying tendencies of prospective primary school teachers]. Educational Technology Theory and Practice, 6(2), 100-119. https://doi.org/10.17943/etku.97311

Sonmez, T. (1994). Consistency, monotonicity, and the uniform rule. Economics Letters, 46(3), 229-235.

Tabachnick, B. G., \& Fidell, L. S. (2001). Using multivariate statistics (4th ed.). Boston, MA: Allyn \& Bacon.

Tezbasaran, A. A. (1997). Likert tipi olcek hazirlama kilavuzu [Likert type scale development guide]. Ankara, Turkey: Turkish Psychological Association Publications.

TUIK. (2011). Household information technology use survey results. Retrieved from http://www.tuik.gov.tr /PreHaberBultenleri.do?id=8572 20.02.2018.

TUIK. (2017). Household information technology use survey results. Retrieved from https://dijitalmaden.com/tuikten2017-year-information-technologies-usage-research.

Vural, S. S., \& Kurt, A. A. (2018). Universiteogrencilerinin bakis acisiyla dijital vatandaslik gostergelerinin incelenmesi [Investigation of digital citizenship indicators through university students' perceptions]. Educational Technology Theory and Practice, 8(1), 60-80.

Yazicioglu, Y. \& Erdogan, S. (2007). SPSS Uygulamali bilimsel arastirma yontemleri [Scientific research methods with SPSS applications]. Ankara, Turkey: Detay Publishing.

Yelken, T. Y. (2005). Ogretim teknolojileri ve materyal tasarimi [Instructional technologies and material development]. Ankara, Turkey: Ani Publishing. 